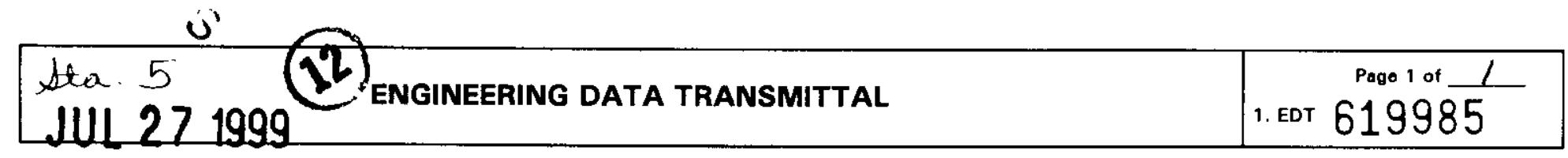

\begin{tabular}{l} 
2. To: (Receiving Organization) \\
Fluor Daniel Hanford, Inc. \\
\hline $\begin{array}{l}\text { 5. Proj./Prog./Dept./Div:: } \\
\text { Plutonium Finishing Plant }\end{array}$
\end{tabular}

3. From: (Originating Organization)
B\&W Hanford Company
$\begin{aligned} & \text { 6. Design Authority/Design Agent/Cog. Engr.: } \\ & \text { A. L. Ramble/R.W. Szempruch }\end{aligned}$
4. Related EDT No.:
N/A
7. Purchase Order No.:
N/A
9. Equip./Component No.:
$\mathrm{N} / \mathrm{A}$
10. System/Bldg./Facility:
2736-ZB

8. Originator Remarks:

This document is being distributed for functional review and approval.

12. Major Assm. Dwg. No.:

11. Receiver Remarks: $\quad$ 11A. Design Baseline Document? $\bigcirc$ Yes $\bigcirc$ No

$\mathrm{N} / \mathrm{A}$

13. Permit/Permit Application No.:

$\mathrm{N} / \mathrm{A}$

14. Required Response Date:

N/A

\begin{tabular}{|l|l|}
\hline \multicolumn{2}{|l|}{15.} \\
\hline $\begin{array}{c}\text { (A) } \\
\text { No. }\end{array}$ & (B) Document/Drawing No. \\
\hline 1 & HNF-4822 \\
\hline & \\
\hline & \\
\hline & \\
\hline & \\
\hline & \\
\hline
\end{tabular}

DATA TRANSMITTED

(F)

\begin{tabular}{|c|c|c|}
\hline $\begin{array}{c}\text { (C) Sheet } \\
\text { No. }\end{array}$ & $\begin{array}{c}\text { (D) Rev. } \\
\text { No. }\end{array}$ & (E) Title or Description of Data Transmitted \\
\hline
\end{tabular}

\begin{tabular}{|c|c|c|c|}
\hline$(\mathrm{F})$ & $(\mathrm{G})$ & $(\mathrm{H})$ & $(\mathrm{l})$ \\
\hline $\begin{array}{c}\text { Approval } \\
\text { nator }\end{array}$ & $\begin{array}{c}\text { Reason } \\
\text { for Trans- } \\
\text { mittal }\end{array}$ & $\begin{array}{c}\text { Origi- } \\
\text { nator } \\
\text { Dispo- } \\
\text { stion }\end{array}$ & $\begin{array}{c}\text { Receiv- } \\
\text { or } \\
\text { Dispo- } \\
\text { sition }\end{array}$ \\
\hline
\end{tabular}

16.

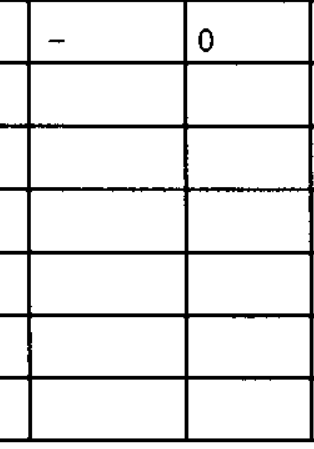

Calc. Note - Consequences

of a Fire in the sorting

and Repackaging Glovebox

in Room 636 of Building

2736-2B - Plutonium

Finishing Plant.

\begin{tabular}{|l|l|}
\hline$S$ & \\
\hline & \\
\hline & \\
\hline & \\
\hline
\end{tabular}

\begin{tabular}{|c|l|}
\hline Approval Designator (F) & \\
\hline $\begin{array}{c}\text { E, S, Q, D OR N/A } \\
\text { (See WHC-CM-3-5, } \\
\text { Sec. 12.7) }\end{array}$ & $\begin{array}{l}\text { 1. Approval } \\
\text { 2. Release }\end{array}$ \\
\hline
\end{tabular}

17.

Reason for Transmittal (G)

KEY

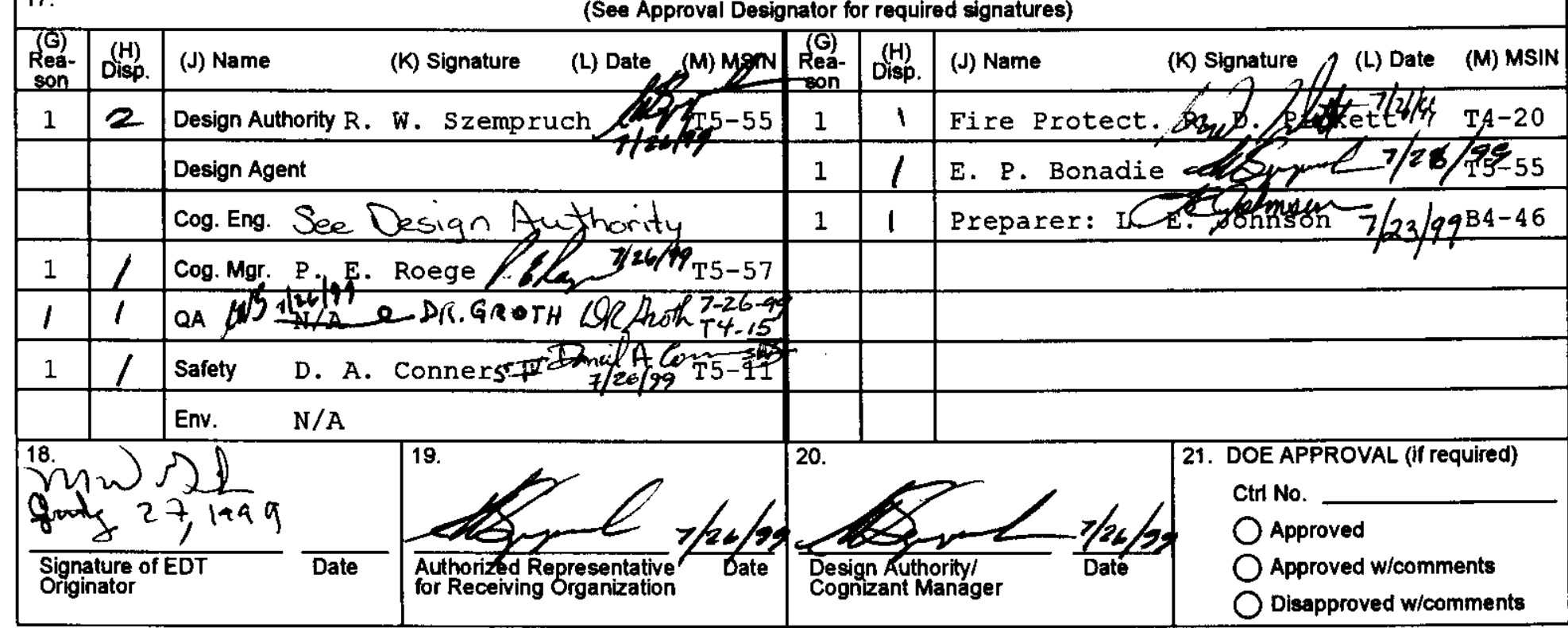

4. Review

5. Post-Review

6. Dist. (Recelpt Acknow. Required)

Disposition (H) \& (l)

$\begin{array}{ll}\text { 1. Approved } & \text { 4. Reviewed no/comment } \\ \text { 2. Approved w/comment } & \text { 5. Reviewed w/comment } \\ \text { 3. Disapproved w/comment } & \text { 6. Receipt acknowledged }\end{array}$

1. Approved

3. Approved w/comment
. Reviewed w/comment

6. Receipt acknowledged SIGNATURE/DISTRIBUTION (See Approval Designator for required signatures) 


\title{
Calculation Note - Consequences of a Fire in the Sorting and Repackaging Glovebox in Room 636 of Building 2736-ZB - Plutonium Finishing Plant
}

\author{
L. E. Johnson \\ Fluor Daniel Northwest, Inc. \\ Richland, WA 99352 \\ U.S. Department of Energy Contract DE-AC06-96RL13200

$\begin{array}{lll}\text { EDT/ECN: } & 619985 & \text { UC: } \\ \text { Org Code: } & 403 & \text { Charge Code: } 10148 \mathrm{BB} 20 \\ \text { B\&R Code: } & \text { EW7002010 } & \text { Total Pages: } 29\end{array}$

Key Words: Fire, Glovebox, packaging

\section{Abstract:}

This Calculation Note provides a conservative estimate of the grams of plutonium released from Building 2736-zB of the Plutonium Finishing Plant as a result of a fire within Glovebox 636, without consideration of mitigation.

TRADEMARK DISCLAIMER. Reference herein to any specific commercial product, process, or service by trade name, trademark, manufacturer, or otherwise, does not necessarily constitute or imply its endorsement, recommendation, or favoring by the United States Government or any agency thereof or its contractors or subcontractors.

Printed in the United States of America. To obtain copies of this document, contact: Document Control Services, P.O. Box 950, Mailstop H6-08, Richland WA 99352, Phone (509) 372-2420; Fax (509) 376-4989.
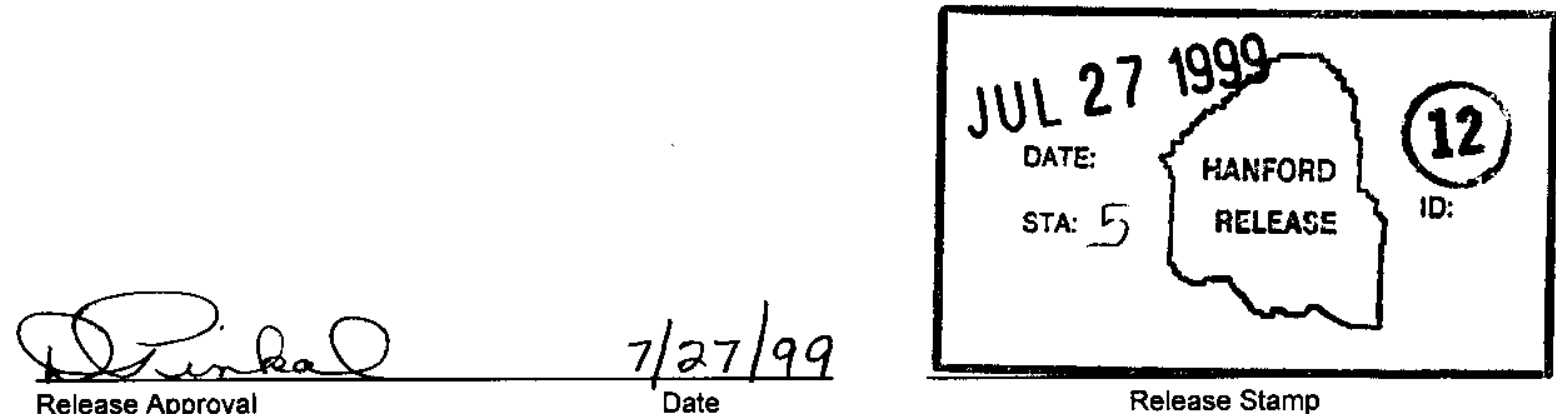

\section{Approved For Public Release}


HNF-4822

Rev. 0

\section{Calculation Note - Consequences of a Fire in the Sorting and Repackaging Glovebox in Room 636 of Building 2736-ZB - Plutonium Finishing Plant}

Prepared by:

Fluor Daniel Northwest, Inc.

For:

B\&W Hanford, Inc.

Date Published

July 1999

Approved by:

B\&W Hanford, Inc.

July 1999

Prepared for the U. S. Department of Energy

FLUOR DANIEL

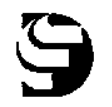

HANFORD, INC. Richland, Washington

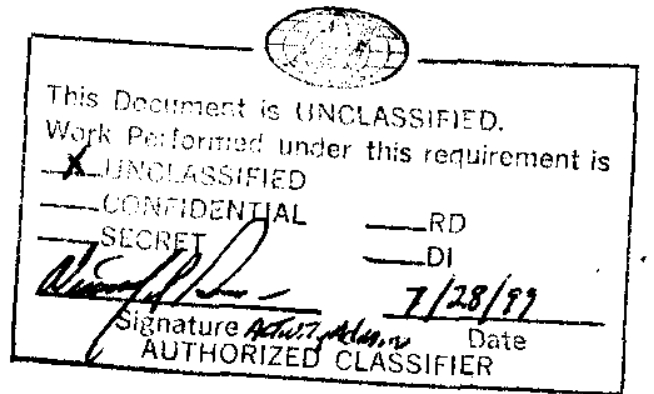

Hanford Management and Integration Contractor for the

U.S. Department of Energy under Contract DE-AC06-96RL13200 
HNF-4822 Rev. 0

This page intentionally left blank. 


\section{TABLE OF CONTENTS}

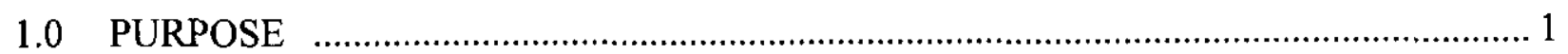

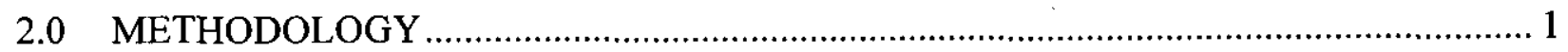

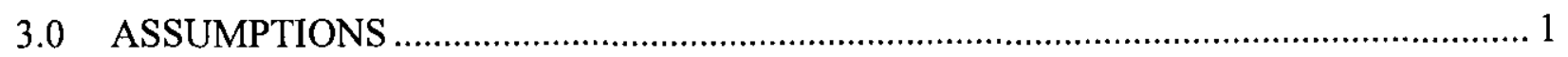

4.0 INPUT DATA

4.1 PLUTONIUM FORM AND QUANTITY ……………................................................ 2

4.2 ASSUMPTIONS REGARDING THE FIRE ............................................................. 3

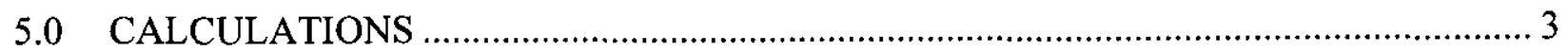

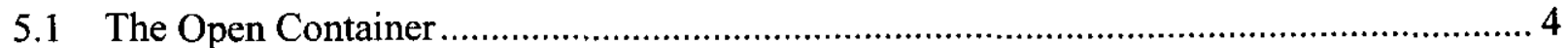

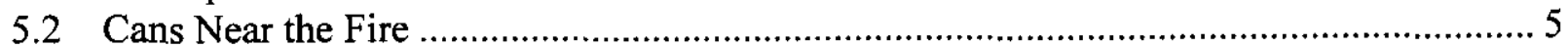

5.3 Leak Path Factor .................................................................................................... 10

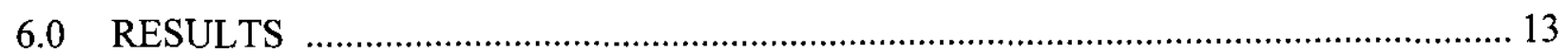

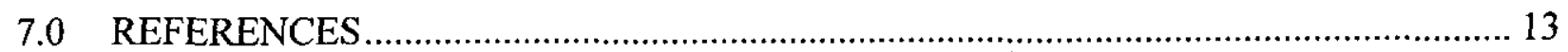

APPENDIX - FIRE AND GLOVEBOX 636 - HEAT TRANSFER CALCULATIONS …...... 15

\section{LIST OF TABLES}

Table 1 Respirable Release Quantity from Vented Cans Containing Corrosion Products or Product Oxide 
HNF-4822 Rev. 0

This page intentionally left blank. 


\section{Calculation Note - Consequences of a Fire in the Sorting and Repackaging Glovebox in Room 636 of Building 2736-ZB - Plutonium Finishing Plant}

\subsection{PURPOSE}

The purpose of this Calculation Note is to provide a conservative estimate of the grams of plutonium release from Building 2736-ZB of the Plutonium Finishing Plant as a result of a fire within Glovebox 636, without consideration of mitigation.

\subsection{METHODOLOGY}

The calculations performed are based on a series of events and conditions that deterministically maximize the quantity of plutonium released from a fire in Glovebox 636 without any mitigation except for the passive confinement characteristics of the 2736-ZB Building shell. Maximizing assumptions and conservative handbook values (from DOE 1994 and related references) are used throughout. The assumed glovebox inventory is the maximum permitted by criticality prevention specifications and of the assumed chemical and physical forms are those that result in the greatest release from the glovebox. Neither the likelihood or credibility of individual conditions nor the specific sequence of events used to arrive at the calculated release are discussed. By so calculating the release, a basis is formed upon which one may assess the influence of existing mitigating features (or absence thereof), on the quantity of plutonium potentially released to the environment. In summary, the calculation provides an answer to the question, "what is the worst release that would occur if nothing were done once the fire started?"

\subsection{ASSUMPTIONS}

See Sections 4.0 and 5.0 .

\subsection{INPUT DATA}

Glovebox 636 is used to repackage containers or packages (hereafter called cans) of plutonium. The need for repackaging is generally driven by the discovery of less than adequate packaging or the need to inspect or sample the contents of the can. This function could involve any can within the entire PFP plutonium inventory. The glovebox could also be used to support a production mode metal brushing and repackaging operation with thermal stabilization of the brushings and broken pieces of plutonium metal.

The Criticality Prevention Specification (CPS) permits up to eight cans with a maximum of $2,500 \mathrm{~g}$ of plutonium each to be present in the Repackaging Glovebox. The CPS does not restrict the chemical form of the plutonium. 


\subsection{PLUTONIUM FORM AND QUANTITY}

The cans could contain plutonium metal (hereafter called metal), metal with reactive and non-reactive corrosion products, oxide from metal burning operations, reactive and non-reactive corrosion products alone from metal brushing operations, product oxide or some other form of plutonium. The cans have a crimped edge at the top and bottom and could have either a welded or soldered side seam.

The quantity of metal, corrosion products or oxide can vary. The quantity of metal in the cans is typically no greater than $2,200 \mathrm{~g}$. The CPS allows up to $2,500 \mathrm{~g}$ in a can. Cans containing metal and corrosion products will have less than 2,200 $\mathrm{g}$ of metal if the can seals leak, because the plutonium from the metal typically react with the in-leaking air, or with hydrogen from the bags used for contamination control, to form reactive and non-reactive corrosion products. This results in a lower quantity of metal.

Metal is typically corroded to some degree. The typical quantity of corrosion products is tens of grams, but there is the potential to have hundreds of grams of corrosion products. It is judged that $100 \mathrm{~g}$ of corrosion products characterizes the upper end of the "typical quantity". This is supported by Ewalt (1999). Ewalt (1999) also provides information showing that $700 \mathrm{~g}$ of corrosion products constitutes the $95^{\text {th }}$ percentile.

Ewalt presented a discussion of a study performed at Rocky Flats concerning the accumulation of reactive corrosion products as a function of in-leakage. The study involved five representative packaging conditions. Within each condition, between 1 and 30 cans were opened and the quantity of corrosion products were weighed. A total of 53 cans were opened and weighed. A total of $40 \mathrm{~g}$ or less of corrosion products were found in 37 of the cans. Six cans contained 40 to $110 \mathrm{~g}$, nine cans contained 110 to $460 \mathrm{~g}$, and one can contained $998 \mathrm{~g}$. While the maximum quantity of corrosion products in Ewalt (1999) was $998 \mathrm{~g}$, it is conceivable that an entire 2,200 $\mathrm{g}$ metal ingot could oxidize to $2,500 \mathrm{~g}$ of oxide.

Cans containing product oxide or oxide from metal burning operations typically contain less than $1,250 \mathrm{~g}$ and are usually stored in slip-lid cans. In this report, oxide from metal burning operations is considered to have similar properties (bulk density, particle size distribution) as that from corrosion products. As a result, this material will be included in the corrosion product category.

From the above discussion it is seen that the quantity of plutonium metal could vary between 0 and $2,200 \mathrm{~g}$, with the CPS limit at $2,500 \mathrm{~g}$. The quantity of powders (oxide, corrosion products, metal fines, etc.) can vary from 0 to $2,500 \mathrm{~g}$. The actual quantity of plutonium assumed to be present in each of the eight cans is developed in Sections 5.1 and 5.2. 
Section 5.0 will show that use of these quantities maximizes the release.

\subsection{ASSUMPTIONS REGARDING THE FIRE}

It is assumed that there are sufficient combustibles, present (in the form of glovebox gloves and plastic bags) that should they be ignited, the subsequent fire contains enough energy to ignite the plastic sheets covering the glovebox windows. The FHA (McKinnis 1998) stated that an $18 \mathrm{~kW}$ fire for two minutes would ignite polymethyl methacrylate (PMMA), the material from which the plastic sheets are made. The quantity of combustibles needed to ignite PMMA is determined next.

SFPE (1988), pg. 2-2 provides the energy release and burning velocity for polypropylene and polystyrene. These compounds are reasonable surrogates for the plastic bags and other materials that might ignite. The energy release and burning velocity for polypropylene and polystyrene are quite similar; an average of the two is used in this analysis. The energy release to be used is $42 \mathrm{MJ} / \mathrm{kg}$ and the burning velocity is $0.026 \mathrm{~kg} / \mathrm{m}^{2}-\mathrm{s}$. Using this data, it is found that an $18 \mathrm{~kW}$ fire for two minutes in duration will occur if the area of the burning material is 6 in. in diameter $\left(0.018 \mathrm{~m}^{2}\right)$ and the quantity is $51 \mathrm{~g}$ of plastic. That is, a 6 in. diameter fire involving $51 \mathrm{~g}$ of plastics can ignite PMMA panels. Since this quantity of plastics is not excessively large, it is assumed that at least $51 \mathrm{~g}$ of combustibles are present with no credit taken for procedural controls and operator training that tell the operator to move the combustibles away from potential ignition sources. Credit is also not taken for the fact that the plastic sheets are only $1 / 16 \mathrm{in}$. thick and form the exterior layers of a plastic-leaded glass composite window. The leaded glass in the middle of the window is $1 / 2$ in. thick. While $18 \mathrm{~kW}$ for two minutes can ignite a plastic sheets, a larger fire is needed to ignite the sheets in Glovebox 636 due to the heat transfer capability of the leaded glass. Nevertheless, it is assumed that the fire is large enough to ignite the PMMA panels.

It is assumed that the combustible material is located around an inner can (contrary to procedure and training) that was just opened. It is assumed that the inner can contains reactive corrosion products (e.g., plutonium hydride or nitride). It is also assumed that the reaction of these corrosions products with air cause ejection of hot particles ("sparks") which land on the combustibles, igniting them.

\subsection{CALCULATIONS}

The fire is assumed to affect the open container as well as the other seven containers in the glovebox. The quantities of plutonium in each can described in the paragraphs below are justified in Sections 5.1 and 5.2

In the analysis below, it is assumed that there is one open can in the middle of the glovebox. Combustible materials surround this can and are ignited by exothermic reactions occurring within the can. This can contains corrosion products and $2,480 \mathrm{~g}$ of metal. 
Surrounding this center can are four cans, each of which is assumed to contain $1,800 \mathrm{~g}$ of metal and $700 \mathrm{~g}$ of corrosion products.

Separated from these five cans (one central can with four cans surrounding) are the remaining three cans. Each of these cans is assumed to contain $700 \mathrm{~g}$ of corrosion products and $1,800 \mathrm{~g}$ of metal.

Sections 5.1 and 5.2 provide the justification for the airborne release fractions (ARF) and respirable fractions (RF) used in the analysis. Section 5.1 discusses the center can. Section 5.2 discusses the other seven cans. In Section 5.3, the respirable quantity released is presented using the ARFs and RFs developed in Sections 5.1 and 5.2, and the inventory discussed Section 4.0.

\subsection{THE OPEN CONTAINER}

The fire starts in combustible materials next to the open container, due to sparks from the reaction of the reactive corrosion products in air. Within the open container are corrosion products and metal. The corrosion products and metal are assumed to be in direct contact with the hot gases from the fire that is assumed to surround the open can.

The can in the center is open. It will be shown below that the respirable release quantity of the powders is very small and the respirable release quantity of the metal is much larger. As a result, the maximum release would occur if the quantity of metal is maximized. Since corrosion products are needed to start the fire, it will be assumed that there are $20 \mathrm{~g}$ of corrosion products and $2,480 \mathrm{~g}$ of metal. The quantity of metal is chosen to be consistent with the CPS. The typical initial quantity of metal is $2,200 \mathrm{~g}$.

The hot gases from the fire will loft some of the corrosion products from the container. This process is called thermal stress in DOE (1994). The airborne release fraction (ARF) for thermal stress of plutonium dioxide is given in Section 4.4.1.1 of DOE (1994). At air speeds of $1.2 \mathrm{~m} / \mathrm{s}$ and temperatures of $800-900^{\circ} \mathrm{C}$, the ARF is $2.5 \times 10^{-4}$. At ambient conditions and an air speed of $1.2 \mathrm{~m} / \mathrm{s}$, the ARF is $5.6 \times 10^{-3}$. At air speeds of $0.1 \mathrm{~m} / \mathrm{s}$, the ARF is about $1 \%$ of these values.

Since the fire is started by sparks from exothermic reactions occurring in the open can, the fire is necessarily near the open can. A fire near the open can having reactive corrosion products exothermically reacting in air should result in temperatures of hundreds of degrees inside the can; far from ambient conditions. A value of $1.0 \times 10^{-3}$ is used for the ARF in this case as the temperature is well above ambient conditions (but maybe not as high as $800-$ $900^{\circ} \mathrm{C}$ ) and the airflow is high as a result of the fire. The value of $1.0 \times 10^{-3}$ is conservative with respect to the ARF at $800-900^{\circ} \mathrm{C}$. The respirable fraction is 0.01 per DOE (1994). The choice of $1.0 \times 10^{-5}$ for $A \mathrm{AF}^{*} \mathrm{RF}$ also matches that suggested for reactive plutonium compounds under thermal stress. 
It is assumed that this can contains $20 \mathrm{~g}$ total of reactive and non reactive corrosion products. The respirable release to the glovebox from heating and lofting the corrosion products is, therefore:

$$
20 \mathrm{~g}\left(1.0 \times 10^{-5}\right)=2.0 \times 10^{-4} \mathrm{~g}
$$

The fire will also affect the plutonium metal ingot. The plutonium metal ingot is assumed to be hot initially due to the effect of the exothermic reaction of the reactive corrosion products. The metal may not be in the form of a single large ingot but may be severely cracked or in small pieces. The heat and increased airflow from the fire intensify the exothermic reactions occurring on the metal. DOE (1994) Section 4.2.1.1.3 provides ARF and RF values for self-sustained oxidation above the ignition temperature of the metal. Experiments show that the ARF for reactions in which plutonium metal having a mass of less than $15 \mathrm{~g}$ burns in air yields a bounding ARF of $1.5 \times 10^{-4}$. Experiments involving bulk plutonium metal having masses of 500 to $2000 \mathrm{~g}$ yields an ARF of $5.0 \times 10^{-4}$. The recommended value from DOE (1994) is $5.0 \times 10^{-4}$ with an RF of 0.5 .

The respirable release from heating the metal is, therefore:

$$
2480 \mathrm{~g}\left(5.0 \times 10^{-4}\right)(0.5)=0.62 \mathrm{~g}
$$

The total release is from the open container is thus $0.62 \mathrm{~g}$ plus $2.0 \times 10^{-4} \mathrm{~g}$ for a total of $0.62 \mathrm{~g}$ (rounded down from $0.6202 \mathrm{~g}$ ).

\subsection{CANS NEAR THE FIRE}

Based on a criticality specification limit, a maximum of eight cans are allowed to be in the glovebox simultaneously. It is assumed that four of the cans are 12 to 18 in. from the can in the middle of the fire. The spacing requirements from the criticality specification is $10 \mathrm{in}$. The four cans form a square around the open can in the center. The sides of the square are 24 to 36 in., with a can at each corner. The glovebox is about $40 \mathrm{in}$. wide and 93 in. long. Using a spacing of 12 to 18 in. places the cans near the glovebox walls, given that the can in the fire is in the center of the glovebox. This is a reasonable placement, as it keeps these cans close at hand but far enough away so as not to disturb the repackaging of the one central can.

The cans at the corners are sealed. Some of the cans are multiple overpack containers, and some may be taped slip-lid cans awaiting seal-out. The slip-lid cans contain brushed plutonium metal. The nested containers hold plutonium metal with reactive and non-reactive corrosion products. However, these containers have one to three cans within the overpack. These cans surround and protect the plutonium metal corrosion products. The cans could also contain plutonium dioxide alone or in combination with reactive corrosion products. 
The fire will heat the cans due to radiant heat transfer. Sealed cans fail at $30-50$ psig (Figure 2-2 of the Thermal Stabilization Addendum to the PFP FSAR). To achieve a pressure of $40 \mathrm{psig}$ requires heating the air in the can to $1130 \mathrm{~K}\left(857^{\circ} \mathrm{C}\right)$. The temperature was determined using the ideal gas law, and assuming a constant volume and an initial inside can air temperature of $30^{\circ} \mathrm{C}$.

Overpressurization due to heating of the can could occur in the following way. The radiant heat from the fire heats the outer can which in turn heats the air and other cans nested inside. As the can heats, it in turn transfers heat to the glovebox atmosphere due to radiant and convective heat transfer. If the primary can over-pressurizes and fails, the air between this can and the next can is exchanged with the glovebox air and acts as an insulating blanket to the conduction heating of the inner can. If the air between the outer and the inner can is cooled due to air exchanges with the air in the rest of the glovebox, convective heat transfer between the hot inner surface of the outer can and the air could keep the inner cans cool. Since the air flow patterns and rates are unknown, it is assumed that convective heat transfer fails to cool the inner surface of the outer container. Using this assumption, heat from the outer can will radiate to the inner can, heating it and the air between this can and the next inner can (if one exists). The heat from the fire might also accelerate the reaction of the corrosion products with the air in the can. The heat transfer calculations in the Appendix shows that radiant heat transfer limits the heating of the can by the fire. The peak temperature reached is $1,283 \mathrm{~K}$. The pressure in the can at this temperature using the ideal gas law is $4.2 \mathrm{~atm}$ or $62 \mathrm{psia}(47 \mathrm{psig})$. It is assumed that the can ruptures at 50 psig. Ignition of the PMMA panels could result in greater heating of the cans, which could result in greater pressures within the can.

In the above scenario no credit is taken for heat transfer to the glovebox floor. In addition, no credit is taken for heat transfer due to convection caused by the increased air currents due to the fire. Finally, the calculation assumed that the heat flux from the fire remains at the same level for the entire heating process, including heating of the plutonium metal to $1,283 \mathrm{~K}$.

While the scenario above can cause pressurization, a more likely reason for can pressurization under these conditions is the generation of gas from the thermal degradation of the plastic bags used for contamination control. Thermal degradation of these bags takes place at much lower temperatures. Since the can volume is small, the addition of a small amount of hydrogen or other thermal degradation product can cause pressures of this magnitude. Since the respirable release quantity is large when the can overpressurizes and vents, it is assumed that the cans overpressurize as a result of one of the above mechanisms.

The rupture of the container due to overpressurization causes some of the corrosion products to be lofted and transported out of the can during depressurization. DOE (1994), Table 4-12 shows the ARF and RF for cans vented at $40 \mathrm{psig}(0.37 \mathrm{MPa})$. The value of the ARF is $2.0 \times 10^{-2}$, and the RF will be taken as 0.33 based on the same table. The ARF and RF were based on experiments run with uranium dioxide $\left(\mathrm{UO}_{2}\right)$ and titanium dioxide $\left(\mathrm{TiO}_{2}\right)$. The uranium dioxide values are used in this analysis. The experiments were performed on $350 \mathrm{~g}$ of oxide sealed in a small container. The oxide was comprised almost entirely of particles of respirable size. The container was pressurized. The seal was broken, and a fraction of particles 
were ejected out of the can. At $50 \mathrm{psig}$, the median diameter of the collected particles was 10 to 25 micrometers (microns). About $1 / 3$ had diameters less than 10 microns (taken to be the respirable size per DOE 1994). This experiment is judged to be reasonably close to the condition where $700 \mathrm{~g}$ of corrosion products are formed by a slow chemical reaction on the surface of the metal with the components of air or hydrogen. It is judged that this reaction could produce very fine particles. As a result, the ARF of $2.0 \times 10^{-2}$ and RF of 0.33 will be used for cans having $350 \mathrm{~g}$ to $700 \mathrm{~g}$ of corrosion products or oxide.

The respirable release from cans having $100 \mathrm{~g}$ of corrosion products is found from Sutter (1983). Sutter shows that the ARF for $100 \mathrm{~g}$ of powder is 0.036 , not 0.02 as it is for $700 \mathrm{~g}$. The respirable fraction remains the same, 0.33 .

Any of the cans could contain just oxide or corrosion products. The oxide would be that from one of the chemical processes that occurred at PFP (or at another DOE site) in the past. Corrosion products could come from an accumulation of brushings or from chemical reactions between the metal and air inleakage from a can having a large breach. The amount of oxide formed by inleakage is limited by can volume. As the oxide layer builds and fills available space within the can, the ability of the air to get to the metal is reduced (i.e., the reaction becomes diffusion limited). The quantity of oxide seen in breached cans can be great, but rarely exceeds $700 \mathrm{~g}$ (information from the Denver Workshop on Plutonium Metal Reaction Products [Ewalt 1999]). However, it is assumed that there could be $2,500 \mathrm{~g}$ in a can due to corrosion to allow for operational flexability.

The respirable fraction of the oxide from PFP processes is no greater than $3 \%$ per the PFP FSAR. Use of this value, rather than the RF of 0.33 found from experiments having almost $100 \%$ respirable particles, yields a respirable quantity of $1.5 \mathrm{~g}$ (from 2,500 times $2.0 \times 10^{-2}$ times 0.03 ). Credit is also not taken for the reduction in ARF as oxide mass is increased. Table 1 of Sutter (1983) shows a reduction in ARF from 0.036 (for the experiment involving $100 \mathrm{~g}$ ) to 0.02 (for the experiment involving $350 \mathrm{~g}$ ).

The respirable release for $2,500 \mathrm{~g}$ of corrosion products vented at $50 \mathrm{psig}$ is judged to be no greater than $4.6 \mathrm{~g}$, the respirable release from venting $700 \mathrm{~g}$ of corrosion products. The respirable fraction for the oxide formed due to reactions of the metal with air is greater than that for product oxide because of the differences in how the oxide is made. However as the oxide fills the available space in the can, the particles are forced closer together. This should decrease the respirable fraction. The experiments in Sutter (1983) show that the ARF decreases a factor of 1.8 as the mass increases by a factor of 3.5 , from $100 \mathrm{~g}$ to $350 \mathrm{~g}$. The ratio of 2,500 to 350 is 7 , so the ARF should decrease by about a factor of 4 (if the effect is linear) due to the much larger mass. The combination of lower ARF and RF coupled with the larger mass is judged to give the same respirable release as from the venting $700 \mathrm{~g}$ of corrosion products. This argument is judged to hold for any quantity of corrosion products between $700 \mathrm{~g}$ and $2,500 \mathrm{~g}$.

The release from the oxide in slip-lid containers is taken from Ballinger et. al. (1987) Table A.6. For a mass of $350 \mathrm{~g}$, the ARF times RF due to venting from a 9 psig is $3 \times 10^{-5}$. For $100 \mathrm{~g}$, the ARF times RF is $2 \times 10^{-4}$. At 17 psig the value of ARF times RF is $6.7 \times 10^{-4}$ for $350 \mathrm{~g}$ and $4.5 \times 10^{-4}$ for $100 \mathrm{~g}$. A value of $3.4 \times 10^{-4}$ will be used for the case of the slip-lid cans 
containing up to $2.500 \mathrm{~g}$ of oxide as permitted by the CPS. The value is the average of the ARF and RF values for $100 \mathrm{~g}$ and $350 \mathrm{~g}$ vented at 9 psig and $17 \mathrm{psig}$. A relatively large pressure is used because the pressure at which the tape between the slip-lid and the can of the slip-lid can fails is unknown, although it is believed to be small. Table 1 contains the results of the release calculations for corrosion products.

Table 1. Respirable Release Quantity from Vented Cans Containing Corrosion Products or Product Oxide.

\begin{tabular}{|c|c|c|c|}
\hline Quantity & $\underline{\mathrm{ARF}}$ & $\underline{\mathrm{RF}}$ & $\begin{array}{l}\text { Respirable } \\
\text { Quantity,g }\end{array}$ \\
\hline $0-100 \mathrm{~g}$ & 0.036 & $\overline{0.33}$ & $0-1.2$ \\
\hline $100-350 \mathrm{~g}$ & -- & -- & $\begin{array}{l}1.2-2.3 \\
\text { (Note } 1)\end{array}$ \\
\hline $350 \mathrm{~g}$ & 0.02 & 0.33 & 2.3 \\
\hline $350-700 \mathrm{~g}$ & 0.02 & 0.33 & $2.3-4.6$ \\
\hline $700-2.500 \mathrm{~g}$ & -- & -- & 4.6 \\
\hline $\begin{array}{l}2,500 \mathrm{~g} \\
\text { in slip-lid cans }\end{array}$ & $\begin{array}{c}3.4 \times 10^{-4} \\
\text { (including RF) }\end{array}$ & -- & 0.86 \\
\hline
\end{tabular}

Note 1 - Respirable quantity is assumed to vary linearly between the end point values.

Table 1 shows that the maximum respirable release occurs for large quantities of corrosion products or oxide. Section 5.1 shows that an additional respirable release could occur if metal were present. The maximum respirable release would occur for $1,800 \mathrm{~g}$ of metal with $700 \mathrm{~g}$ of corrosion products. Greater quantities of corrosion products would have a lesser quantity of metal, and therefore a lower total respirable release. This is because the respirable release of corrosion products does not change with quantity above $700 \mathrm{~g}$.

Applying the ARF and RF from Section 5.1 to $1,800 \mathrm{~g}$ of metal yields a respirable quantity of $0.45 \mathrm{~g}$. Adding this to the maximum respirable quantity of $4.6 \mathrm{~g}$ for corrosion products yields a total respirable release of $5.05 \mathrm{~g}$.

The form and quantity of plutonium in the cans can vary as discussed in Section 4.0. Therefore, it is assumed that each of the seven cans contains $700 \mathrm{~g}$ of corrosion products and $1,800 \mathrm{~g}$ of metal, and that each of the cans heats to the point that they overpressurize and breach. The total respirable release from the fire is therefore:

$$
(0.62 \mathrm{~g} \text { from the single can })+7(5.05 \mathrm{~g})=36 \mathrm{~g} \text {. }
$$

An additional conservatism is that this assumes that all of the respirable release escapes out the openings of the cans. If each of the lids are blown fully open (e.g., $95 \%$ of the 
circumference of the lid is breached) this is not much of a conservatism. However, if one or more of the lids opens only a small amount (e.g., $5 \%$ of the circumference of the lid is breached), only a portion of the suspended respirable material will escape. The rest will remain in the can due to agglomeration, sedimentation or impaction with the lid.

The releases above are based on the assumption that the fire heats the cans and the air within the cans to the point that the increased internal pressure causes all of the cans within the nested arrangement to rupture in such a fashion that all of the vented material is released. This is not expected to actually occur. Szempruch (1984), Figure 12, shows that the opening in cans pressurized to $100 \mathrm{psig}$ is very small.

Consider a set of nested cans. The heat from the fire causes the largest can to heat first. That, in turn, could cause the largest can to pressurize first and subsequently fail first. The cans in this case fail sequentially. The vented release from the small can goes into the large can pressurizing it to a lesser degree. The depressurization of the large can only results in a fraction of the vented release escaping.

Assume the open volume of the inner can is pressurized to $50 \mathrm{psig}$ ( $64.7 \mathrm{psia})$. When the inner can fails, the air expands to fill the large outer can. The pressure reaches $10 \mathrm{psig}$ $(24.7 \mathrm{psia})$ in the large overpack can given a free volume in the inner can of $0.2 \mathrm{~L}$ and a free volume in the outer can of $1.3 \mathrm{~L}$. The fractional release $F_{1}$ due to depressurization of the outer can is:

$$
F_{1}=10 /(14.7+10)=0.4
$$

Now consider the case where all cans vent at the same time. The small can vents into the large can. The fraction $F_{2}$ of the contents in the large can that escape is:

$$
F_{2}=50 /(14.7+50)=0.77
$$

However the volume of the small can is only one-sixth of the large can, so that only a fraction of the volume released contains suspended particulate. The fraction of the suspended particulate is judged to be no greater than 0.4 . Use of 0.4 is therefore a reasonable bound for this case.

If the small can pressurizes first and ruptures, the release into the large can will be smaller than that discussed in either situation above because the large can is also at pressure. Only a fraction of the contents of the small can will vent into the large can. When the large can finally fails, $77 \%$ of the initial release plus some of the simultaneous release is transported out of the can. Again a fractional release value of 0.4 is judged to be reasonable. 
The phenomena described apply to the release of the corrosion products or oxide due to pressurization. The release from the metal is a relatively long term release as compared to the immediate release of the powder during venting. The $\mathrm{ARF}$ and $\mathrm{RF}$ for metal burning were taken from experiments in which the metal was burned in the open. In this case, the metal is burning in a much more enclosed condition, and the ability of air currents to loft the oxide is much less. That which is lofted could agglomerate and settle back onto the metal due to the small head space. Lack of ready air flow will hamper the burning process. As a result it is judged that the 0.4 release factor also applies to metal reactions. It is concluded that only 0.4 of the suspended plutonium would escape given a small opening in the large can.

The release into the glovebox is therefore:

$$
(0.62 \mathrm{~g})+(7(5.05)(0.4))=14.8 \mathrm{~g} \text { (rounded from } 14.76 \mathrm{~g})
$$

\subsection{LEAK PATH FACTOR}

The fire is assumed to start due to sparks from the exothermic reaction in air of reactive corrosion products within an open container of plutonium metal. The combustibles are the plastic from bags used for contamination control. These bags enclose the containers. Spare bags are brought into the glovebox for use in repackaging. The glovebox gloves could also be considered a combustible. The fire starts in the plastic and is assumed to propagate to the glovebox gloves and windows. The glovebox windows are a layered arrangement comprised of a 1/16 in. PMMA sheets, $a^{1 / 2}$ in. leaded glass panel in the middle followed by a 1/16 in. PMMA sheet. The fire starts and may quickly involve the plastic. However, the PMMA sheets will not ignite until they absorb sufficient energy. This will take some time. Data from McKinnis (1998) showed that with $51 \mathrm{~g}$ of plastic involved in a fire, it takes two minutes to ignite PMMA panels. It may take longer in this case, as there will be heat transfer to the leaded glass. As a result, there is time for an orderly evacuation. There are no life-threatening aspects to this fire as there would be if, for example, flammable liquids or flammable gases were involved, or if the windows were thin sheets of PMMA rather than the layered arrangement. PMMA softens at $100^{\circ} \mathrm{C}$, begins to decompose at $170^{\circ} \mathrm{C}$, and self-ignites at $450^{\circ} \mathrm{C}$. At high temperatures, a PMMA fire propagates rapidly when the decomposition products become mixed with sufficient oxygen to cause a rapid surface reaction. In the case analyzed here, the leaded glass will help transfer heat out of the thin PMMA sheet on the inside of the glovebox. Even when this sheet starts to burn, the products of combustion will initially remain inside the glovebox. The leaded glass will prevent the exterior sheet of PMMA from igniting until later, if at all. Because of this, the operations staff exits down the corridor and out of the cold side of the facility and not through the door into Room 637 and out of the facility as they might under "life threatening" situations. This assumption is made because the operators are trained to use the normal route (through the facility to the "cold" side) unless their life is threatened (e.g., progress blocked by smoke or flame). As a result, there are no direct flow paths to the environment from Room 636 or 637.

The fire in Glovebox 636 involves about 50 lbs of combustibles, most of which are gloves. Each glove weighs $2.5 \mathrm{lbs}$ per the PFP Fire Protection engineer. There are 14 gloves in 
the glovebox for a total of $35 \mathrm{lbs}$. The PMMA sheets are one-sixteenth of an inch thick, and the length and width are $22 \mathrm{in.} \mathrm{and} 14 \mathrm{in}$. respectively. Using a density of $1 \mathrm{~g} / \mathrm{cm}^{3}$, each sheet weighs $0.7 \mathrm{lb}$. There are 6 large windows each containing two sheets of PMMA and six small windows. The small windows are one-third the size of the large windows. Total PMMA weight is $11 \mathrm{lbs}$. The heat content of the fire is taken to be 8,000 Btu/lb per Shaffer and Leonard (1999).

The ventilation system shuts down when there is a fire in the glovebox. (If the ventilation fails to shut down, the results are less severe, per Chapter 3 of the Plutonium Metal Can Opening and Thermal Stabilization Addendum to the PFP FSAR). Assuming that the gloves and bag-in port fail, the smoke from the fire and suspended plutonium fill Room 636 . Other adjacent rooms (e.g., Room 637, the NDA lab and the corridor) may also fill. No credit is taken for capture of smoke and aerosol in the exhaust HEPA filters located in Room 636, for induced flow from Room 636 to the stack via the exhaust system, or for the action of the automatic sprinkler systems within the room. At this point, no credit is taken for the ability of the HEPA filters to remove the aerosol.

As a result, the plutonium aerosol will mix with the aerosol from the smoke and a large percentage will remain within the room. The fraction that is transported out of the room is called the leak path factor. Two reports are used to determine the leak path factor. The first report regarding leak path factor comes from Buijs (1988). This report presents the results of an experiment designed to determine the fraction of aerosol deposited within a room in which a glovebox fire was occurring. The room analyzed was similar in size to Room 636 . The length was $34 \mathrm{ft}$, width $12 \mathrm{ft}$ and height $16 \mathrm{ft}$; Room 636 is $23 \mathrm{ft}$ by $17 \mathrm{ft}$ by $14 \mathrm{ft}$. The surface area of the walls and ceiling of the room in the test chamber is $1,880 \mathrm{ft}^{2}$. The surface area of the walls and ceiling in Room 636 is $1,511 \mathrm{ft}^{2}$. The ventilation rate in the test room can be adjusted to between 150 and $2,000 \mathrm{ft}^{3} / \mathrm{min}$. Most of the analysis was performed with a flow rate of $1,200 \mathrm{ft}^{3} / \mathrm{min}$. The ventilation rate to the hot side of $2736-\mathrm{ZB}$ is $6,500 \mathrm{ft}^{3} / \mathrm{min}$. Room 636 occupies about $10 \%$ of the hot side area, and therefore receives about $10 \%$ of the ventilation flow or $650 \mathrm{ft}^{3} / \mathrm{min}$.

In the test, five sheets of PMMA, each weighing about $1 \mathrm{~kg}$, were stacked horizontally in a steel frame. The plates are separated by $10 \mathrm{~cm}(4 \mathrm{in}$.). Each plate is square, having $12 \mathrm{in.} \mathrm{long}$ sides, and is 0.3 in. thick. There is a 2.4 in. hole drilled in the center of each plate. The plates are ignited by burning ethanol in a tray beneath the PMMA. The hole in the center of the plates acts as a chimney, assuring rapid ignition and burning of the PMMA. In the test, cerium oxide was spread onto the PMMA plates. The result was that $2 \%$ of the cerium oxide escaped the test chamber via the ventilation system. About 33\% remained in the PMMA residue. The rest was plated out on the walls. The test conditions closely parallel the condition analyzed for Room 636 with the exception that the contaminant was spread onto the PMMA panels prior to ignition rather than lofted into the air. Also, Buijs considered continuing ventilation flow, whereas the $2736-\mathrm{ZB}$ ventilation system is shut down in the case of a fire.

There are two main differences between the test in Buijs (1988) and in the case being analyzed. The first is that the smoke and aerosol that escapes Room 636 is still within the facility and can plate out or settle. The second is that the ventilation system in Buijs (1988) was running, where in the case being analyzed there is no ventilation flow. The expectation is that 
the leak path factor for a small fire like that in Glovebox 636 would be less than that found in Buijs (1988) which had an air exchange every 5 minutes (found from dividing the room volume, $6,528 \mathrm{ft}^{3}$, by the ventilation flow rate, $1,200 \mathrm{ft}^{3} / \mathrm{min}$ ).

The second leak path factor case to consider is found in Shaffer and Leonard (1999) who present the results of a computer simulation of a fire in the Nuclear Materials Storage Facility at Los Alamos. In this analysis, a one hour fire involving $\mathrm{Pu}$ solutions is assumed to occur in the NDA Laboratory at Los Alamos. The fuel loading is $393 \mathrm{~kg}, 17$ times more than the postulated fire load in Glovebox 636. It is assumed that the solutions are oxidized, and a suspended plutonium dioxide aerosol is formed. A total of $1 \mathrm{~g}$ of respirable oxide was assumed to be suspended by the fire. This is similar to the condition analyzed for Room 636. The ventilation system is assumed to be inoperable (as it would be for Room 636). The simulation modeled the facility doors remaining open for the first five minutes of the fire and then closing. The volume of the building in the NDA Lab simulation is $531 \mathrm{~m}^{3}, 3.5$ times larger than Room 636 . The experiment in Buijs contained a $185 \mathrm{~m}^{3}$ room having $5 \mathrm{~kg}$ of combustible material. The facility modeled by Shaffer and Leonard exhausted airflow through cracks in the doors due to the action of a steady $30 \mathrm{mph}$ wind. Direct airflow through cracks between the doors and the frame was modeled. The building HEPAs were assumed to remain functional at $99.98 \%$ efficient. With a crack width of $1 \mathrm{~mm}$, the leak path factor was $0.93 \%$; with a crack width of $2 \mathrm{~mm}$, it was $2 \%$. Both cases assumed a steady $30 \mathrm{mph}$ wind for 18 hours. For the case of a $10 \mathrm{mph}$ wind and a $0.5 \mathrm{~mm}$ crack size, the leak path factor was $1.0 \times 10^{-4}$.

The fire analyzed by Shaffer and Leonard is much larger than that in Glovebox 636 . The building analyzed by Shaffer and Leonard has a volume of $531 \mathrm{~m}^{3}$. The volume of $2736-\mathrm{ZB}$ is $4,712 \mathrm{~m}^{3}$ (from $132 \mathrm{ft}$ long, $90 \mathrm{ft}$ wide and $14 \mathrm{ft}$ tall). The volume of Room 636, 637 and the corridor outside Room 636 , the rooms into which the smoke and aerosol travel, is about $950 \mathrm{~m}^{3}$. So the volume in the Glovebox 636 fire case is larger but the fire load is much smaller. As a result, the leak path factor of $10^{-4}$ for the $10 \mathrm{mph}$ wind case might be an appropriate factor to use for the Glovebox 636 case.

A third leak path analysis was performed for the case of a fire in Building 371 at Rocky Flats (Colwell 1999). The fire was assumed to have a heat rate of $1 \mathrm{MW}$ for the equivalent of $1,000 \mathrm{~s}$ (ramp from 0 to $1 \mathrm{MW}$ in $300 \mathrm{~s}$, remain at $1 \mathrm{MW}$ for $600 \mathrm{~s}$, ramp to $0 \mathrm{MW}$ in $600 \mathrm{~s}$ ). The total energy release was $10^{9} \mathrm{~J}$, or $10^{6} \mathrm{Btu}$. The fire modeled in Shaffer and Leonard involved $864 \mathrm{lbs}$ of combustibles having a heat rate of $8,000 \mathrm{Btu} / \mathrm{lb}$ for a total heat input of $7 \times 10^{6} \mathrm{Btu}$. The fire in Glovebox 636 had a heat output of $0.4 \times 10^{6} \mathrm{Btu}$ (from $50 \mathrm{lb}$ times 8,000 Btu/lb). The building was about the size of $2736-\mathrm{ZB}$. A total of $1,000 \mathrm{~g}$ were assumed to be suspended in the building during the fire. The LPF for the base case of a fire with a $5 \mathrm{mph}$ wind was $0.8 \%$ and with a $20 \mathrm{mph}$ wind speed the LPF was $2.6 \%$. Extrapolating to a $30 \mathrm{mph}$ wind yields a leak path factor of $4 \%$. However with a $30 \mathrm{mph}$ wind and extrapolating the effect of a larger fire yields a leak path factor of about $2 \%$. These results are similar to that obtained by Shaffer and Leonard (of 0.1 to $5 \%$ for crack sizes of 1 to $5 \mathrm{~mm}$ ). With no wind, the leak path factor was found to be $0.08 \%$.

With no fire, Colwell (1999) found that the leak path factor was $1.8 \%$ based on the effects of a $5 \mathrm{mph}$ wind on the facility. Both Colwell (1999) and Shaffer and Leonard (1999) 
found that greater quantities of soot result in greater removal of the aerosol and therefore smaller leak path factors.

Use of a $1.8 \%$ leak path factor for the Glovebox 636 fire case is judged to be inappropriate. Building 371 at Rocky Flats has roll-up doors on the docks. One of these roll-up doors faces the prevailing wind. The second door is $90^{\circ}$ from the wind. The airflow through both doors is modeled so as to maximize the effect of the wind. Building 2736-ZB is surrounded on three sides by other PFP buildings. Only the west side is open to winds. The prevailing winds are from the northwest and west. Rooms 600 and 602 are on the west side of 2736-ZB. These rooms are not normally occupied and contain mechanical equipment. There is only one corridor that supplies both rooms and only one door out into the rest of the facility. The exterior doors are about $30 \mathrm{ft}$ from the corridor. There is a door from the rooms into the corridor. This is much different from the Rocky Flats case where a roll up door on a dock enters a main corridor and a separate roll-up door is on the side of the facility. follows:

A leak path factor of $0.5 \%$ will be used in this analysis. The basis of the choice is as

1. Colwell (1999) showed a leak path factor with no fire of $1.8 \%$ but argued that for fires less than $1 \mathrm{MW}$ a valve of $0.1 \%$ should be used based on their revised model. Sufficient detail, however, was not provided to assess the changes in the model that resulted in the factor of 20 reduction in leak path factor. Assuming a duration of 10 minutes, the heat rate of the Glovebox 636 fire is $40,000 \mathrm{Btu} / \mathrm{min}$ or $0.7 \mathrm{MW}$. A factor of 4 reduction was judged to be appropriate based on the differences in building layout, and exterior features, and fire heat rate. A value of $0.1 \%$ could have been chosen based on the heat rate, however a value of $1 \%$ was suggested for fires having a heat rate of greater than $1 \mathrm{MW}$.

2. A leak path factor of $2 \%$ was obtained by Buijs in a similar sized room having 12 air changes per hour. A reduction to $0.5 \%$ is judged appropriate for the Glovebox 636 fire that had no ventilation flow.

\subsection{RESULTS}

Use of $0.5 \%$ results in a release from the facility of:

$$
14.8 \mathrm{~g}\left(5.0 \times 10^{-3}\right)=0.074 \mathrm{~g}
$$

\subsection{REFERENCES}

Ballinger, M. Y., S. L. Sutter, W. H. Hodgson, 1987, New Data for Aerosols Generated by Releases of Pressurized Powders and Solutions in Static Air, NUREG/CR-4779, U.S. Regulatory Commission, Washington, D. C. 
Buijs, K, de Dalmassey, B. C., 1988, Contaminated Smoke: A simulation of the Heavy Metal containing Aerosols from Fires in Plutonium Gloveboxes, EUR 11809, Joint Research Center, Karlsruhe, Federal Republic of Germany.

Colwell, R. G., 1999, Use of CONTAIN 2.0 to Determine Leakpath Factors Due to Specific Building 371 Accidents, CALC-371-NA-000531, Rocky Flats Environmental Technology Site, Kaiser-Hill Company, Golden, Colorado.

DOE, 1994, Airborne Release Fractions/Rates and Respirable Fractions for Non-reactor Nuclear Facilities, DOE-HDBK-3010-94, U.S. Department of Energy, Washington D.C.

Ewalt, J. W., 1999, Plutonium Metal Corrosion Products - Denver Workshop, HNF-4459, Fluor Daniel Hanford, Inc., Richland, Washington

McKinnis, D. L., 1998, Fire Hazard Analysis for Plutonium Finishing Plant Project, HNF-SDCP-FHA-004, Rev. 0, B\&W Hanford Company, Richland, Washington

SFPE, 1988, Handbook of Fire Protection Engineering, Society of Fire Protection Engineering, Boston, Massachusetts.

Shaffer, C., and M. Leonard, 1999, Leak Path Factor Analysis for the Nuclear Materials Storage Facility, paper given at the 1999 Safety Analysis Working Group Conference on June 1999, Portland, Oregon.

Sutter, S. L., 1983, Aerosols Generated by Releases of Pressurized Powders and Solutions in Static Air, NUREG/CR-3093, U.W. Nuclear Regulatory Commission, Washington D.C.

Szempruch, R. W., 1984, The Effectiveness of Corrective Actions Taken to Preclude Events Involving Tin Cans and Plutonium, RHO-HS-SA-59P, Rockwell Hanford Company, Richland, Washington 
HNF-4822 Rev. 0

\section{APPENDIX}

FIRE AND GLOVEBOX 636

\section{HEAT TRANSFER CALCULATIONS}


HNF-4822 Rev. 0

This page intentionally left blank. 
HNF-4822 Rev. 0

FLUOR DANIEL NORTHWEST

DESIGN ANALYSIS

Canc. Ni. 001

Revision

Page No.

Contraxulob No.

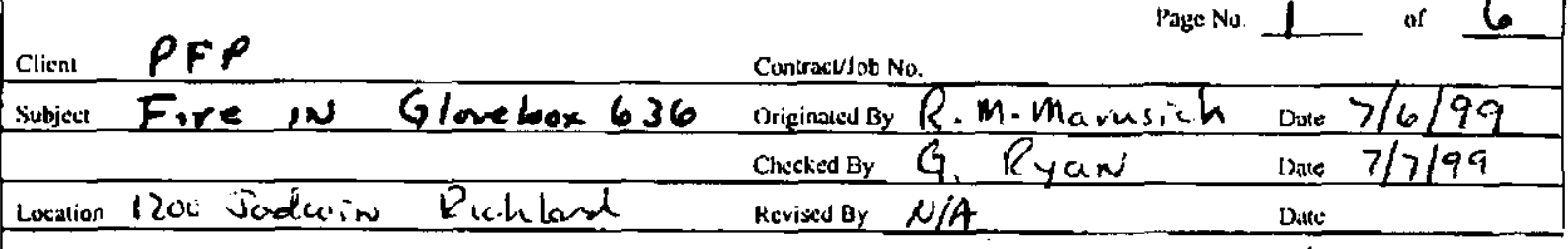

Fine in Glavebox 636 -Heat Tromafer Caliculahou

Assure that a fine car start w the plastic.

at he flow of the glares. Assume l kg of plastic is involved in the fine.

From SFPE, 19rr, Handbook of Freprotechin Engineering

Heat of reach ion for polypropylene. $43.2 \mathrm{~mJ} / \mathrm{kg}$ Total heat $1 \mathrm{~kg}(43.2 \mathrm{~mJ} / \mathrm{kg})=43.2 \mathrm{MJ}$ burn rake $=0.018 \ldots \mathrm{kg} / \mathrm{m}^{2}-5$

Assure fire is 12 inches ind da $=0.073 \mathrm{~m}^{2}$ burn rate $=\left(0.018 \mathrm{~kg} / \mathrm{m}^{2}-\mathrm{s}\right)\left(0.073 \mathrm{~mm}^{2}\right)=0.0013 \mathrm{~kg} / \mathrm{s}$ heat rate $=(0.0013 \mathrm{~kg} / \mathrm{s})(43.2 \mathrm{~mJ} / \mathrm{kg})=0.056 \mathrm{~mJ} / \mathrm{s}$ - $56 \mathrm{kw}$

burn tire $21 \mathrm{~kg} / 0.0013 \mathrm{~kg} / \mathrm{s.2.770s.}$

Assume $0.1 \mathrm{~kg}$ of plashes. Assume meat $1 / 10$ as longe Area $=0.0073 \mathrm{~m}^{2}$

burn rate $=\left(0.018 \mathrm{~kg} / \mathrm{m}^{2}-\mathrm{s}\right)(0.0073)=0.00013 \mathrm{~kg} / \mathrm{s}$ heat rate $6 \mathrm{k \omega}$

burs time $=770$ s.

E-NW-123A (SeR)

17

July 1999 
HNF-4822 Rev. 0

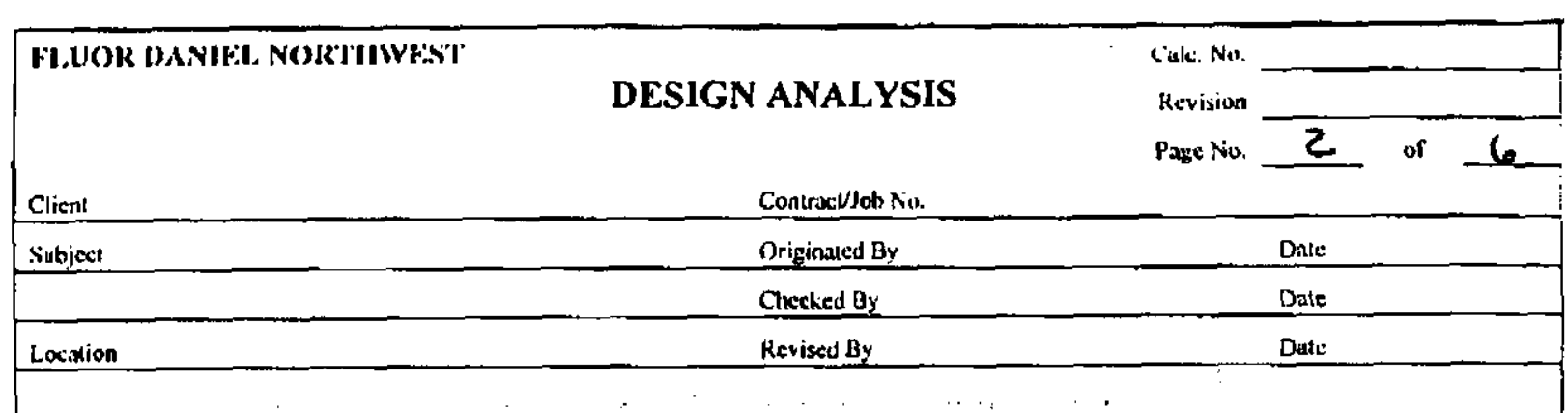

Heat flux an containers.

Pu so in rested containers.

longest is 7 in. tall, 4.25 in dea. 1.5L volume t

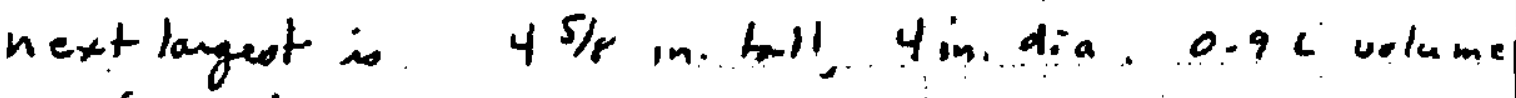
(Tanto can)

Pu metal is in a soles can.

Assume can" is 12 inches from inter of fine.

Area of large can facing the fire (only half of the avar)

$$
\frac{\pi}{2}(4.25 \mathrm{in})(7 \mathrm{in})=47 \mathrm{in}^{2}
$$

Area of fine.

$1 \mathrm{~kg}$ plash fire es 12.n. diarretem $0.1 \mathrm{~kg}$ black fire is $0.0073 \mathrm{~m}^{2}$ area

$$
=3.8 \text { in. dea meter }
$$

(round to 4 in.)

Need flare hey ht to get siciface area of fire.

E-NW-123A (5948)

18

July 1999 
HNF-4822 Rev. 0

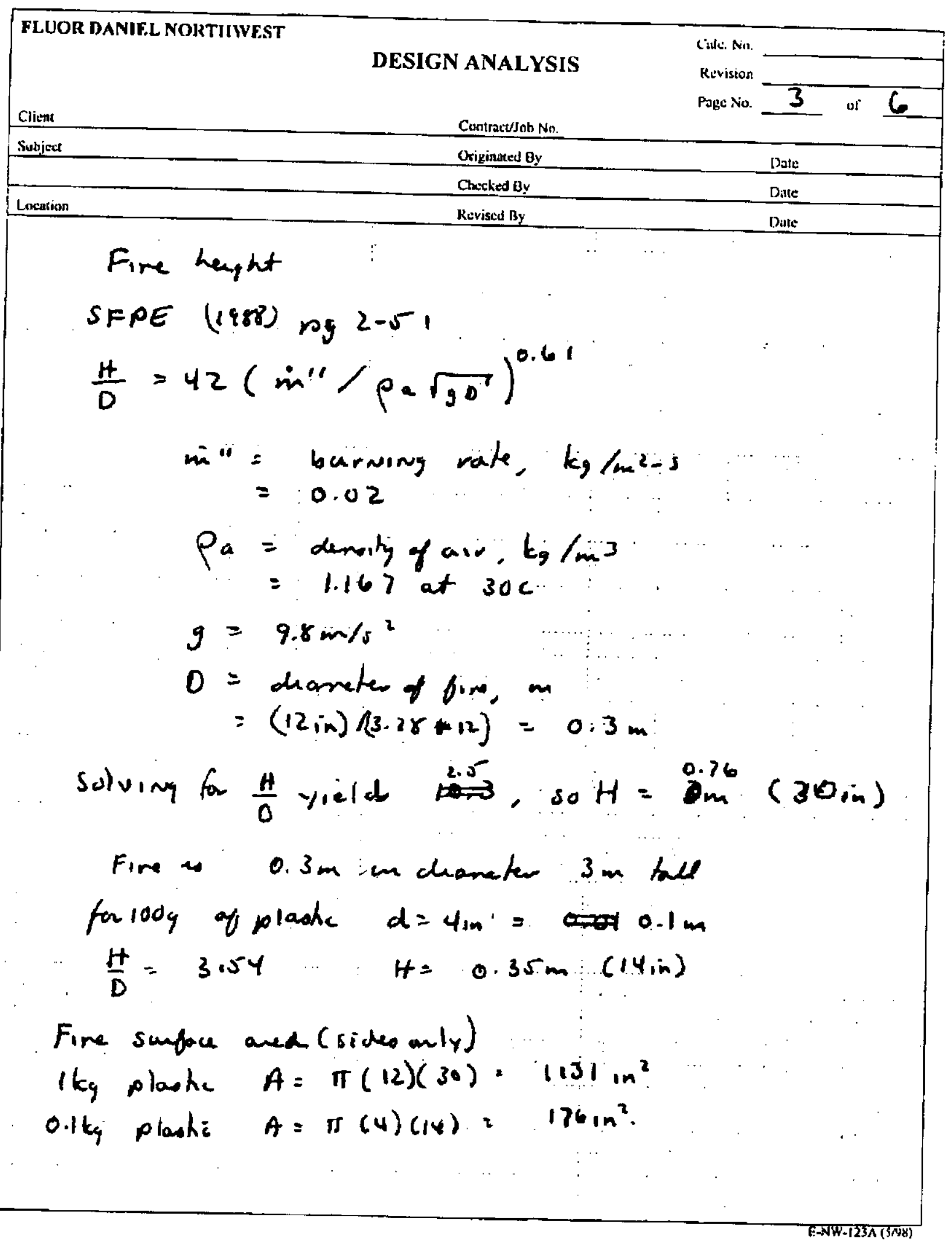


HNF-4822 Rev. 0

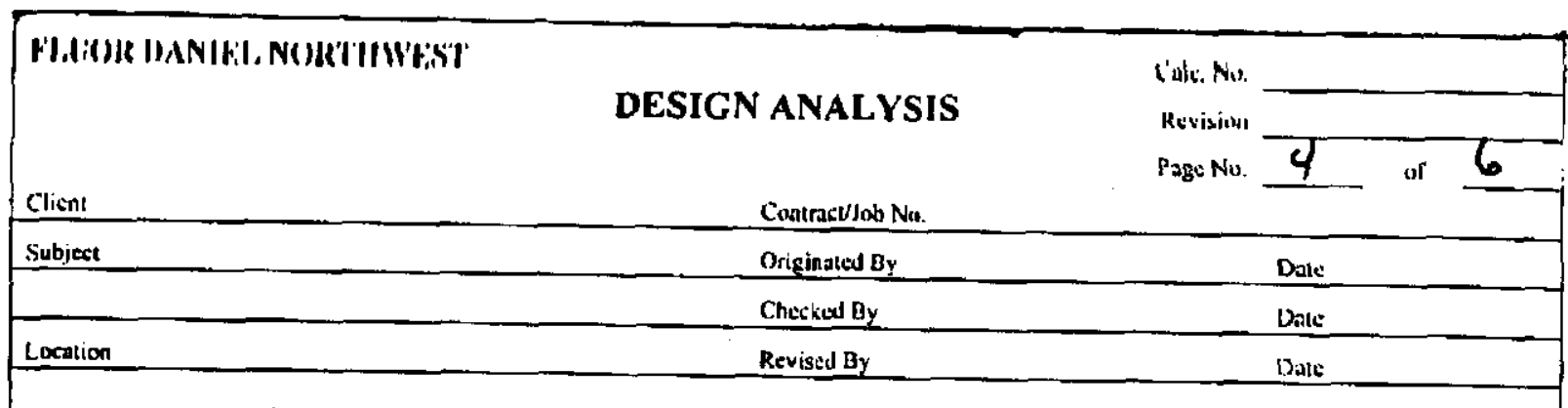

Fraction of heat of fire to can Iqware distance away from fire: Assure duct heating

$$
\text { (and for }
$$

For the $1 \mathrm{~kg}$ ploce care.

Heat to con

$$
\frac{56 k \omega}{11311 n^{2}}\left(47 n^{2}\right)=2.3 k \omega
$$

For the $0.1 \mathrm{~kg}$ plicate case it at to con

$$
\frac{6 k \omega}{176 \mathrm{in}^{3}}\left(47 \mathrm{n}^{2}\right)=1.6 \mathrm{kw}
$$

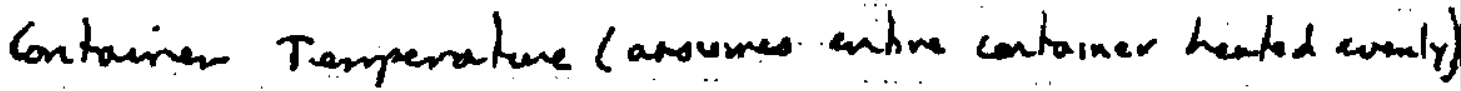
apure: Vic in. walls en can

$$
\begin{aligned}
& V_{\text {Tinge can }}=\pi(4.25)(7)(1 / 16)+2\left(\frac{\pi}{4}\right)(4.25)^{2}(1 / 16) . \\
& =5.8 \mathrm{~m}^{3}+1.8 \mathrm{in}=7.6 \mathrm{in}^{3} \\
& =124 \mathrm{~cm}^{3} \\
& v_{\text {tomato } \mathrm{cm}}=\pi(4)(4.675)(1 / 16)+2\left(\frac{\pi}{4}\right)(4)^{2}(1 / 16) \\
& =3.7 \mathrm{in}^{3}+1.6 \mathrm{in}^{3}=5.3 \mathrm{in}^{3} \\
& \text { Total }=210 \mathrm{~cm}^{3}
\end{aligned}
$$

E- NW-123 [3/198)

20

July 1999 
HNF-4822 Rev. 0

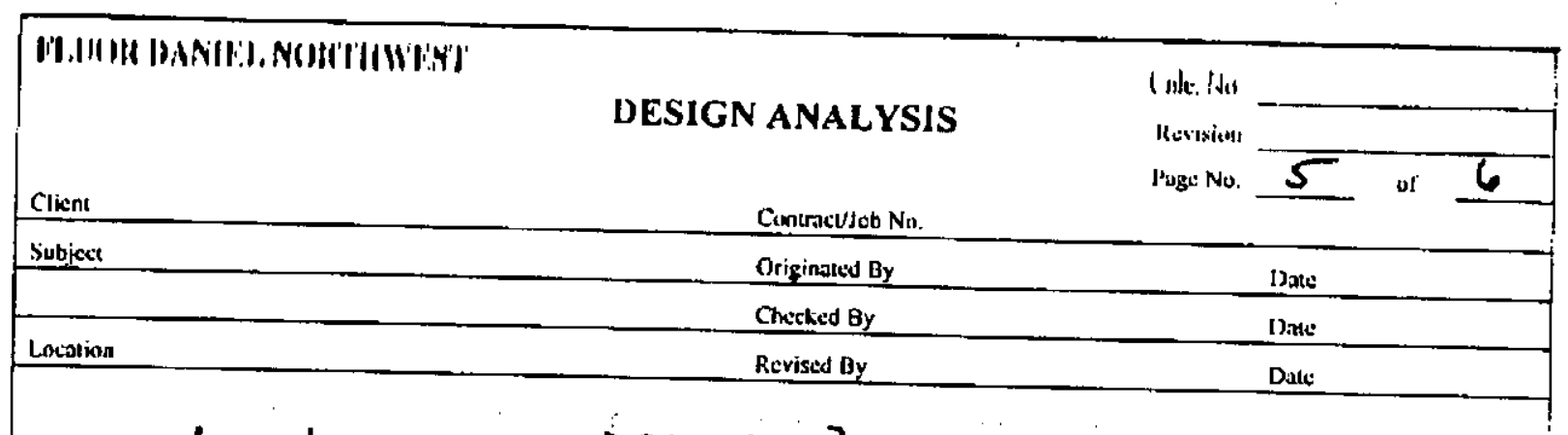

$$
\begin{aligned}
\text { density of iron }= & 7.8, / \mathrm{cm}^{3} \\
\text { mane iron }=1645 & \\
\text { specific heat of iron } & =0 . \frac{12 \mathrm{cal}}{9-\mathrm{c}} \\
& =0 . \frac{12 \mathrm{cal}}{\mathrm{g}-\mathrm{c}}\left(164 \mathrm{sg}_{\mathrm{g}}\right)
\end{aligned}
$$

$$
\begin{aligned}
& \operatorname{mans} P_{u}=2500 q \\
& c_{p} P_{u}=\frac{9 \mathrm{cal}}{\text { mole-c }}\left(\frac{2500 q}{239, \ldots w l)}\right)=94 \mathrm{cal} \\
& \text { 5. Wick, "Pa Hand bosk }
\end{aligned}
$$

con temperature ( no heat trapper out)

$$
Q=\left(m C_{p}\right) \Delta T
$$

I ty plash ic

$$
\begin{aligned}
\frac{(2300 \mathrm{w})(770 \mathrm{~s})}{4.147 \mathrm{~J} / \mathrm{cal}} & =\left[(197.4+94) \frac{\mathrm{cal}}{\mathrm{c}}\right] \Delta T \\
\Delta T & =145: 2 \mathrm{c}
\end{aligned}
$$

$0.1 \mathrm{~kg}$ plash care.

$$
O T=1010 \mathrm{C}
$$

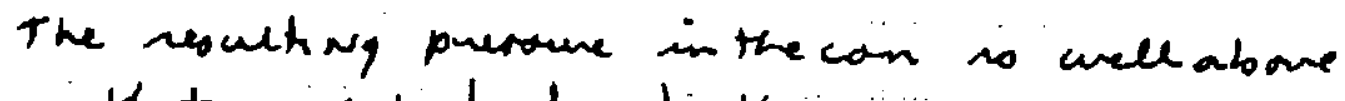
that needed to bunt the can.

E-NW-123A (BN)

21

July 1999 
HNF-4822 Rev. 0

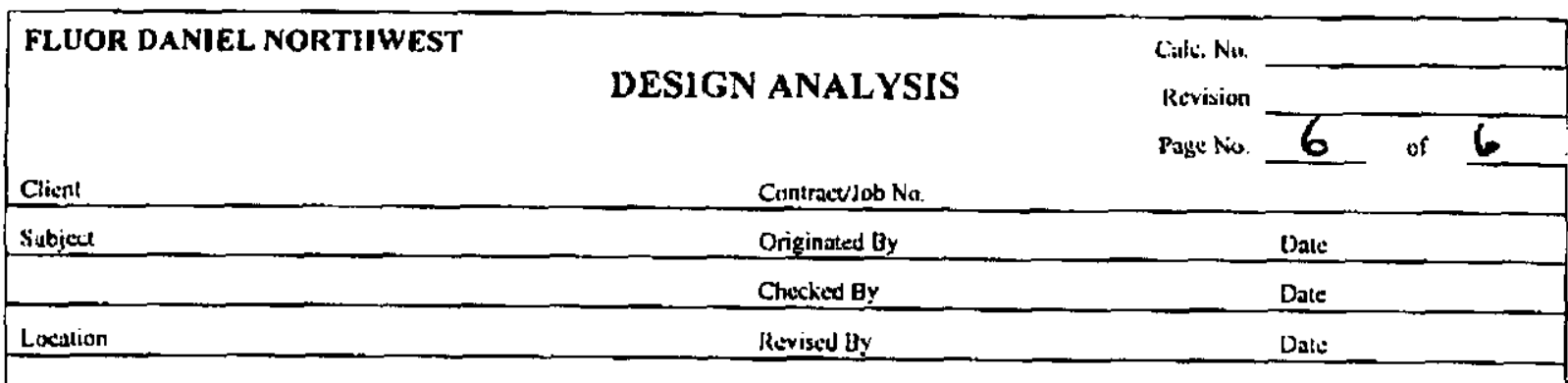

Heat Flux out of cons.

consider only radiation

radiation beat flux es given by:

$$
\begin{aligned}
& q_{\text {rural }}=\sigma \varepsilon A\left(\tau_{\text {com }}^{u}-\tau_{\text {ar }}^{u}\right) \\
& \sigma=5.67 \times 10^{-8} \mathrm{\omega} / \mathrm{m}^{2}-K^{*} \\
& A=47 \mathrm{~m}^{2}=0.03 \mathrm{~m}^{2} \text { half of the con } \\
& \varepsilon=0.28 \text { fo dirty facing away }
\end{aligned}
$$

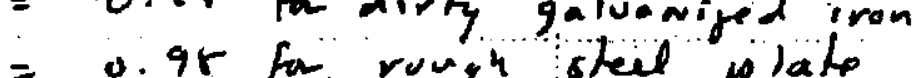

$$
\begin{aligned}
& \text { un } 0.5
\end{aligned}
$$

1 kg plank care

$T_{\text {con }}$ when $g_{\text {rad }}=g_{\text {fir o }}=2.3 \mathrm{tw}$

$$
T_{\text {con }}=1283 \mathrm{~K}=1010 \mathrm{c}
$$

$0.1 \mathrm{~kg}$ plank cone

$$
\begin{aligned}
& g_{\mathrm{rad}}=g_{\text {fir }}=1.6 \mathrm{ku} \\
& r_{\text {can }}=1172 \mathrm{~K}=899 \mathrm{c}
\end{aligned}
$$

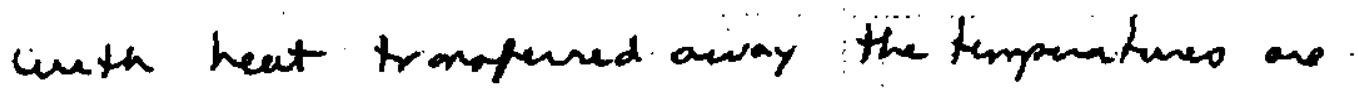

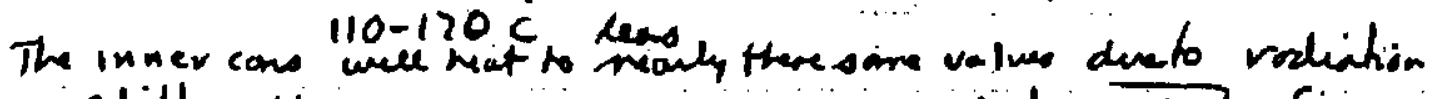
still the con can pressurize and burst from at there temperntives.

the outer $\mathrm{cm}$.

E-NW-123A (3,28)

22

July 1999 
HNF-4822 Rev. 0

Practloe 1342901112

Publiction Date 01Marss

Attrachment 02 - Sheet 1 of 1

FLUOR DANBI NORTHWEST

TECHNICAL PEER RLVIEWS

\section{CHECKLIST FOR TECANICAL PEER REVIEW}

Document Reviewed: HNF-4822, CALCULATION NOTE: CONSEQVUECES OF A FRE IN THE SORTING

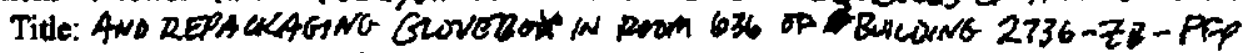

Author: R.M. MAtersicH

Date: $7 / 19 / 99$

Scope of Review: ENTIRe pocumonT (INCLVDING APPONOIX)

Yes No* NA

[ 4 I ] [ ]* Previous reviews complete and cover analysis, up to scope of this review, with no gaps.

[ $\boldsymbol{y}[$ [ ] ] Problem completely definod.

[x] I ] ] Accident scenurios developed in a clear and logical manner.

[X] [ ] [ ] Necessary assumptions explicitly stated and supported.

[ ] [ ] $[x]$ Computer codes and data files documented.

[ ] [ [x] Data used in calculations explicitly stated in document.

[x] [ ] [ ] Data checked for consistency with original source information as applicable.

[X] [ ] ] Mathematical derivations checked including dimensional consistency of results.

[X] [ ] ] Models appropriate and used within range of validity or use outside range of established validity justified.

[x] [ ] ] Hand calculations checked for errors. Spreadshect results should be treated exactly the same as hand calculacions.

[][]$[x]$

[ ] $][x]$

[ ] $][K]$

Softwre input corroct and consistent with document reviewed.

Software output consistent with input and with results reported in document reviewed.

Limits/criteria/guidelines applied to andysis results are appropriate and referenced.

$[\mathrm{l}][\mathrm{x}]$

[x][ ] ]

$[x][][]$

$\{x]\{\}]$

[ ] $[x] * *$

Linits/criteria/guidelines checked against references.

Safety margins consistent with good enginearing practices.

Conclusions consistent with analytical results and applicable limits.

Results and conclusions address all points required in the problem statement.

Format consistent with applicable guides or other standards.

Review calculations, comments, and/or notes are attached.

[ ] ] [x] Tracesbility

[x][ ] ] Document approved (for example, the reviewer affirms the technical accuracy of the document).
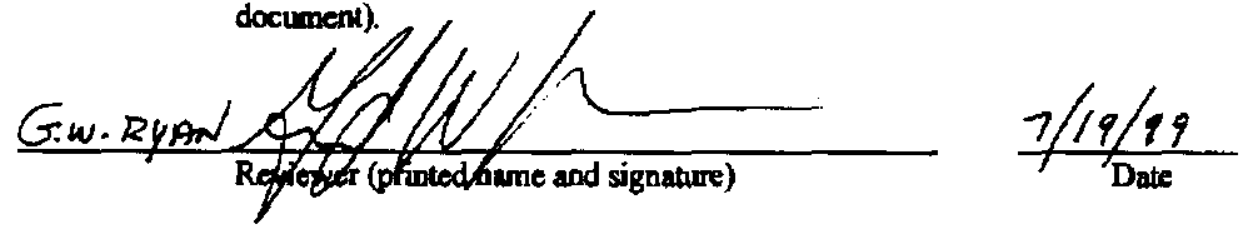

- All "no" responses must be explained below or on an additional shect.

** Any calculations, comments, or notes generated as part of this review should be signed, dated, and altached to this checklist. Such material should be labeled and recorded in such a manner as to be intelligible to a technically qualified third party. 
HNF-4822 Rev. 0

FLUOR DANIEL NORTHWEST

TECHNICAL PEER REVIEWS

\section{CHECKIIST FOR TECHNICAL PEER REVIEW}

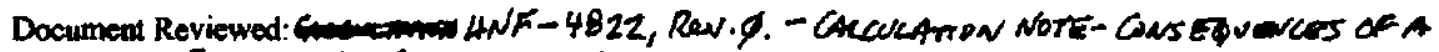

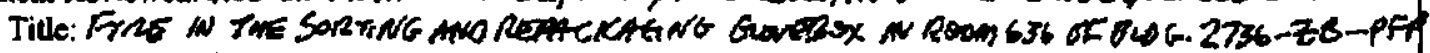

Author: R.M. MmousiCN

Date: $7 / 23 / 991 / 30$

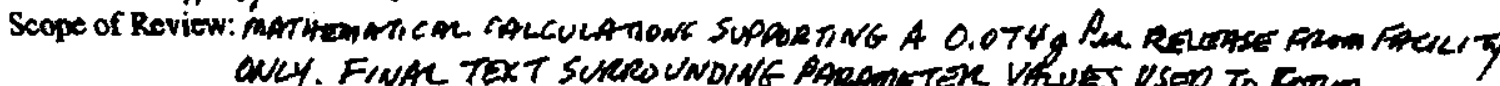
Yes No* NA CONCLUSION NOT REVIENED.

[MI ] [ ] ** Previous reviews complete and cover analysis, up to scope of this review, with no gaps.

[ ] [ ] [M Problem completely defined.

[ ][ ] [xa Accident scenarios developed in a clear and logical manner.

[ ][ ] $K$ ] Necessary assumptions explicitly stated and supported.

[ ] [ ] [r] Computer codes and data files documenced.

[X] [ ] [ ] Daka used in calculations explicitly stated in document.

[r] [ ] [ ] Data checked for consistency with original source information as applicable.

[K] [ ] ] Mathenatical derivations checked including dimensional consistency of results.

[ ] [ ] [X] Madels approprizte and used within renge of validity or use outside range of established validity justified.

[r] [ If ] Hand calculations checked for errors. Spreadsheet results should be treated exactly the same as hand calculations.

[ ] $][$ [

[ ] ] $][\infty]$

Software input correct and consistent with document reviewed.

[ ] $][x]$

Software output consistent with input and with results reported in document reviewed.

Limits/criteria/guidelines applied to analysis results are appropriate and referenced.

Limits/criteria/guidelines checked against references.

[ ] ] $][x]$

Safety margins consistent with good engincering practices.

[ ] $][x]$

Conclusions consistent with analytical results and applicable limits.

[ ] $][x]$

I ] $\mathrm{I}[x]$

Results and conclusions address all points required in the problem statement.

[ ] $[x]^{* *}$

Format consistent with applicable guides or other standands.

[ ] ] $][x]$

Review calculations, comments, and/or notes are attached.

[X] [ II ] Document approvod (for example, the revicwer affirms the technical accuracy of the document). Ste STAtomert of SePpe ARove.

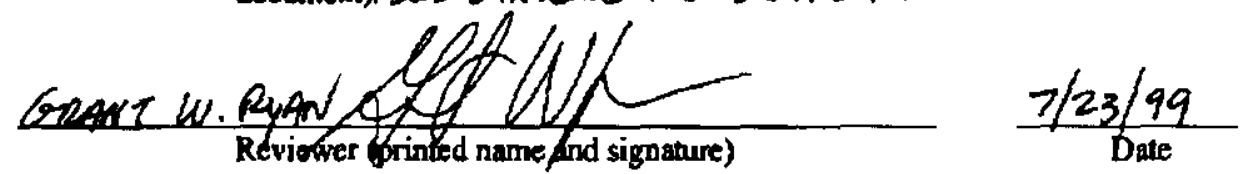

"All "no" responses must be explained below or on an additional sheet.

** Any calculations, conments, or notes generated as part of this review should be signed, dated, and attached to this checklist. Such material should be labeled and racorded in such a manner as to be intelligible to a technically qualified thind party. 


\section{DISTRIBUTION SHEET}

To

Flour Daniel Hanford, Inc.

\section{Project Title/Work Order}

Calc. Note - Consequences of a Fire in the Sorting and Repackaging Glovebox in Room 636 of Building 2736-ZB - Plutonium Finishing Plant
From

$B \& W$ Hanford Company
Page 1 of 1

Date July 27,1999

EDT No. 619985

ECN No.

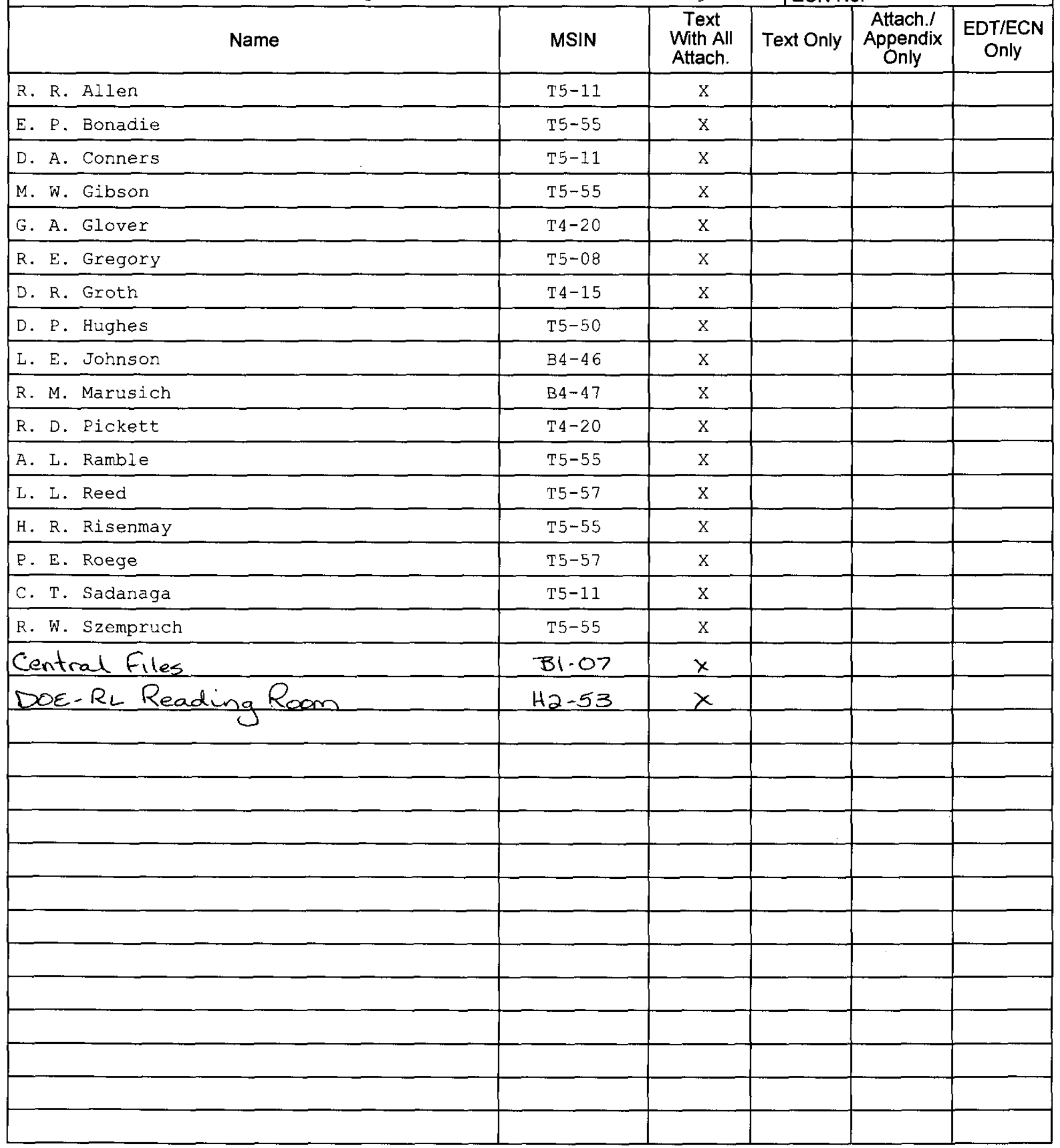

